\title{
Mabel Constanduros
}

\author{
Different voices, voicing difference
}

Gilli Bush-Bailey

On 3 October 1929, The Stage published its weekly column on 'The Variety Stage', beginning with a review of the current entertainment on offer at Oswald Stoll's 'people's palace of entertainment', the London Coliseum:

\begin{abstract}
Making her first appearance in variety here this week is Mabel Constanduros, an artist who has achieved considerable fame in broadcasting and has added thereto with appearances at concert centres. Miss Constanduros has made the study of the cockney woman and girl her particular work, and whether she is suggesting the poor little childmother looking after her youngest sister and selling lavender to keep the home fires burning, the prim marm who directs a children's concert and makes eyes at the curate, or the mixture of hard work, good temper, and complaint that goes to the making of Mrs Buggins, she is always true to life in her character drawing. Monday afternoon found her suffering somewhat from nervousness in her new environment, but her greeting was sincere, and it was clear that Miss Constanduros has many admirers already and will add greatly to their number. ${ }^{1}$
\end{abstract}

As the voice of BBC Radio's The Buggins Family, Mabel Constanduros was among a new generation of performers to make her name on the 'wireless' in the safety of the studio broadcast, where her audience was imagined but unseen. Broadcasting fame soon led to the demand for live stage appearances where, at the London Coliseum, her very visible audience were arranged over three vast tiers of seating and could number anything up to 2,500 people. The 'nervousness in her new environment', picked up here by the Stage reviewer, is hardly surprising. The moment, as depicted by Constanduros in her 1946 autobiography Shreds and 
Patches, is more elaborately described, emotionally heightened and culturally complex:

I was engaged to top the bill at the Coliseum [...] and I felt no triumph at all. I was just terror-stricken. This was a job of which I knew nothing. If I had been engaged to act in a play, I should at least have known how to set about it but I had no idea how to cope with a variety audience and felt secretly that my work was unsuitable for the variety stage. (Constanduros, 1946: 49)

It had been only four years since Mabel had successfully auditioned for the BBC. In that time she had become a familiar voice to the growing number of households buying their own wireless set and listening in to the BBC's National or Regional service where The Buggins Family had quickly become a firm favourite. ${ }^{2}$ Writing and performing the voices for at least six of the characters in the everyday stories of her London 'cockney' family, Constanduros's creation of the cantankerous, but always comical, Grandma Buggins was particularly well loved. So, was this sudden rise to 'stardom' the reason why Constanduros writes of being 'paralysed with fright' as she waited in her 'lovely dressing room, the star room', reduced to a state of 'shaking and feeling extremely sick' (Constanduros, 1946: 50)? Although Constanduros's place at the top of the bill demonstrates the power of broadcast fame to provide a shortcut from the more usual repertory stage apprenticeship of the day, she was not a stranger to live performance. In fact, it was as a result of someone seeing her perform one of her monologues on the amateur stage that she had been invited to audition for the BBC in 1925. So the issue here perhaps was less the fear of a live audience, but rather more a fear of the cultural and social context of that audience:

At that time - it will hardly be believed - I had never been inside a variety theatre. In my youth they were considered most unsuitable for young ladies [...] I should have jumped at an offer to go on the legitimate stage, but the prospect of being a variety artist did not allure me at all. (Constanduros, 1946: 49)

Shreds and Patches returns again and again to her felt conflict between legitimate and illegitimate entertainment, the still active divide between high and low art. The popularity she gained in the emerging industry of radio entertainment gave her access to the legitimate theatre she identified with, but the tension of social place, and placing herself professionally, is a recurring element in her writing, particularly in the reflective tone of her autobiography: 'Because I was relegated to that section of 
radio called Variety I was known as a variety artist, though I think of myself first as a writer and secondly as a straight actress' (Constanduros, 1946: 64).

Variety theatres, for all that had been done to expel the rackety inheritance of the nineteenth-century music halls and transform them into respectable places of popular entertainment, were simply outside the frame of the 'legitimate' stage profession that Constanduros envisaged for herself. As a broadcast performer at pains to express her liking and respect for her variety colleagues and their 'extreme competence', nonetheless Constanduros still saw her working world as separate and superior to theirs. Her initial contract for appearances over a period of eight weeks included dates in variety theatres in London, Leicester, Bristol and Manchester; the last she found particularly 'terrifying', as her northern audience were 'far less easily moved to laughter'. She speaks in self-deprecating terms of her 'ignorance', of the 'stroke of luck' that took her to the 'coveted position' at the top of the bill, and her sense of being an 'imposter' in that branch of the profession. She also counters these expressions of admiration for the variety world with a story of a particularly rough Saturday night when 'hardly anyone in the theatre seemed to be sober'. She nicely concludes that 'it was too lonely a life and the strain on [her] nerves too great' to accept any further contracts for venues where being heard was the main criterion for success (Constanduros, 1946: 52-3).

The explanation that Constanduros gives for initially overcoming her palpable revulsion for the 'feverish brightness one associates with Variety' is the familiar reason that many use to negotiate the gaps between the social milieu of their upbringing, the ambition for self determination and their immediate needs - money.

Still, the salary they offered seemed to me then enormous. I had my son to educate, and I have always had an irresistible urge to try my hand at any new job which offered itself, just to see if I could do it, so I signed the contract, hastily put together an act and bought some dresses. (Constanduros, 1946: 50)

The pressing financial need is, of course, accounted for in the seemingly unavoidable expenditure for a middle-class parent - the fees for her son's schooling at preparatory and public school. There is also though the hint of a characteristic, sometimes reckless, spirit of adventure in Constanduros's acceptance of the challenge, followed swiftly by the apparently haphazard, almost off-hand approach to preparing 
performance materials and buying suitable clothes. There are conflicting energies at work here, of seriousness and an almost careless concern, that speak to the twenty-first-century reader of the precariousness of the times; the structure of feeling that was the cultural backdrop of interwar Britain. This was a culture in which the majority would soon gain the vote, and in which a new generation of middle-class women would work to reform their class identity and renew their certainties as they pursued new aspirations. Mabel Constanduros's writing uses many voices to work out her own place in the positions that women were negotiating in both private and public spheres. Her autobiography, her many published plays and monologues, The Buggins Family and a wide range of other materials for radio offer an opportunity to explore a particular cultural moment. It was a time of reviewing, making and remaking the norms of middle-class life, transmitted to ever-growing numbers of listeners across Britain and abroad through the monopoly on stability and authority held by the BBC. Broadcasting grew swiftly from its infant days at the BBC's London headquarters in Savoy Hill, and Mabel Constanduros was among its many forgotten female pioneers, carving out a professional practice and personal agency that is sometimes unselfconsciously revealed and, at others, deliberately veiled.

This chapter focuses on the different voices, tones and modes of address that Constanduros used in her public writing and professional correspondence. Her autobiography, written while her now-married son was in India on active service, continually returns to the depiction of herself as the successful artist but reluctant working mother, torn between economic need and her much-loved boy, Michael, from whom she 'hated being away' (Constanduros, 1946: 53). It considers her attitude to professionalism, particularly within the emerging industry of radio entertainment, and its alliance with and appropriation for the project of middle-class respectability. Juxtaposing the voice in her autobiographical writing, newspaper interviews, contracts and correspondence preserved in the BBC's written archives, this chapter attends to the shifting register of her voice as the wronged writer negotiating a better fee or doggedly chasing up her copyright. In her many letters to the Authors' Society (held by the British Library), she asks for legal advice and representation against unscrupulous publishers, while simultaneously attempting to get around paying fees for membership of the organisation that she wishes to act on her behalf. As a co-writer, sometimes fighting for joint rights or choosing to shelter behind the man she is working with - and it does always seem to have been a man - Constanduros can be found 
insisting on proper credit and fees according to her greater professional experience. As a performer of her own material, she argues for the right to perform outside the $\mathrm{BBC}$, claiming copyright for the commercial exploitation of her most enduring character creation, Grandma Buggins.

Recordings of Constanduros's broadcasts, particularly The Buggins Family, sound strange to the modern listener, not least in their representation of 'cockney' voices and attitudes. ${ }^{3}$ Even though films from the period can do much to acclimatise the modern ear, there is still much work to be done in exploring the aural conception and reception of performance practices in that period of relatively near-history. But it would be foolish to underestimate the power of the radio voice and the part that Constanduros's broadcast work played in delivering the greater task to 'inform, educate and entertain': the vision for the BBC that John Reith inscribed and that has been maintained by successive generations serving in that 'temple of the arts and muses' (Higgins, 2015: 39).

The $\mathrm{BBC}$ was not the only place for voices interested in capturing the attention of women up and down the country. 1928 saw fifteen million women gain the right to vote on equal terms with men, and there was much to negotiate across the shifting ground for women in the domestic sphere and beyond in the aftermath of the First World War, and the seemingly brief pause before a second. Alison Light draws attention to E. M. Delafield's Diary of a Provincial Lady, published weekly in the leftleaning, modernist magazine Time and Tide (1929), ${ }^{4}$ followed, a little later, by Jan Struther's 'Mrs Miniver', published in The Times (1937-39). ${ }^{5}$ Both offer humorous takes on society through the eyes of the central female character, a wife and mother struggling, but managing, of course, to maintain a fitting lifestyle in the ever-changing picture of uppermiddle-class family life. As Light notes, for the 'upper' and increasingly just the 'middle' class, the burning question in the immediate aftermath of the First World War was where domestic servants might be found and how to avoid losing them (Light, 1991: 119-20). The troublesome cook, the emotional governess, the string of defecting housemaids that worried Delafield's 'provincial lady' were still relevant to many households reliant on the labour of 'other' women. But 'living-in' servants give way to the 'daily help', and the cheerful 'charlady' who 'came in and did' for Mrs Miniver became an increasingly familiar figure as an object of 'affectionate' fun and bemusement to her employer.

The working-class wife and mother is central to the families in which Constanduros's 'cockney' characters are situated. In some ways such characters simply reinscribe conservative class values, but do they also work to 
disturb and re-evaluate the old categories of 'them' and 'us' that preoccupy the middle class in the ongoing project of establishing class position and defining the all-important hegemonic 'we'? In Grandma Buggins Constanduros established a redoubtable, resolute 'cockney' grandmother on the airwaves (Figure 33), later visualised, in the minds of the public at

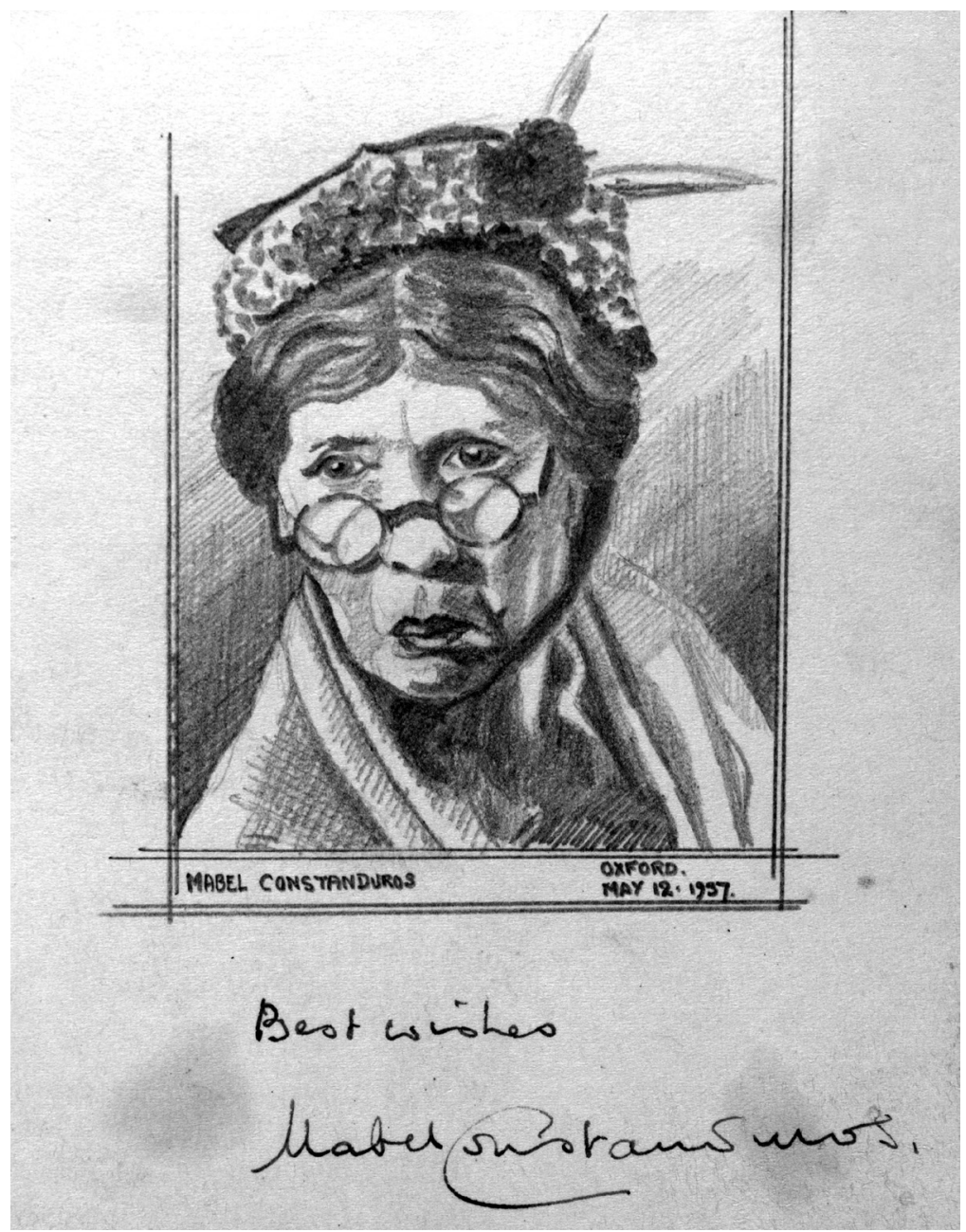

33 Unattributed sketch of Mabel Constanduros as

Grandma Buggins, 1937. 
least, by Giles in the Express newspaper comic strip cartoon and, arguably, reaching forward to the twenty-first-century in British comedy actress Catherine Tate's television character, Nan. ${ }^{6}$ These are not rosycheeked grandmothers of the middling sort or wide-aproned nannies of the upper-middle-class nursery. Constanduros's 'Grandma' was a cussed old matriarch ${ }^{7}$ who was popular enough to be used to broadcast recipes during the food shortages of the Second World War, and on film being shown the latest in post-war kitchen design. ${ }^{8}$ How Mabel Constanduros came to find her own 'voice' through giving voice to her cockney characters, how she established her professional practice and from it voiced agency as script writer, performer and author, is at the heart of the present enquiry. It is also interesting to explore how her writing maps across the larger project of quieting middle-class anxiety, reassuring and adapting in the face of the rapid changes that the interwar years brought to both public and private expressions of British domestic life.

\section{Finding her voice}

Mabel Tilling was born in 1880 into a comfortable middle-class London family, her father being the managing director of a successful bus company built up by his father, Thomas Tilling. ${ }^{9}$ Mabel was educated at Mary Datchelor School in Camberwell. As her autobiography records, the strain of early success there took its toll: 'my health broke down for I was only fourteen when I got into the sixth form and was working with girls three years my senior - so I was sent to school at the seaside' (Constanduros, 1946: 28). Mabel thought little of the finishing school she was later sent to, considering that 'the fees were extremely high, the standard of education was incredibly low. I said so and was not popular' (1946: 30). After this, her father offered to pay for her to have a university education at Cambridge's Girton College, but her mother wanted her to stay at home. Constanduros's autobiography effortlessly elides stories from her past with reflections on the present - the 1940s - touching only lightly on moments in the twenty-five or more years between her leaving school and being offered a place 'in the first Radio Repertory Company' (1946: 40). By 1925 Constanduros was 45 years old, a wife, and mother of an 8-year-old son when her professional life began.

A clue to the almost complete absence from her narratives of her husband, from whom she derived her professional name, might be found in a small moment of reflection on her parents' refusal to consider her request to go to a drama school: 
My parents decided that my wish to go on the stage was only a craze so many girls had it, but forgot all about it when the Right Man came along. Did they ever reflect how much less likely one would be to say 'Yes' to the wrong man if one had work in which one was passionately interested? (Constanduros, 1946: 31)

Exactly why Athanasius (Ath) Constanduros was 'the wrong man' is far from clear, but in one of the few remarks made against the otherwise 'pleasant life' of 'wonderful holidays twice a year' and no 'worry about money' that Mabel enjoyed with her parents is the observation that her life was too 'sheltered', and that, like so many other generations of young women, she had been led to believe that being married was all that was needed for a woman to 'live happily ever after'. Mabel and her 'beloved sister Norah' married the Constanduros brothers in 1907 when Mabel was 27. They 'lived side by side, eventually in Sutton', a suburb on the Surrey side of London, 'upon small incomes' and a great deal of determination it seems (1946: 31-2). Athanasius was an insurance broker who continued to live in Sutton until his death in July 1937, by which time Mabel had not only rented a flat in central London but also owned her own cottage in West Sussex. It is not clear exactly when she moved from the marital home, but the briefest of references to circumstances that may have contributed to their unrecorded separation - there is no evidence of a divorce - tells of the loss of two children:

I had a little boy called Tony to whom I was entirely devoted, and he died when he was four years old. Even today I cannot write about it. Michael was my third and only surviving child, and I daresay I was an over-anxious mother. $(1946: 33)^{10}$

Michael was born in 1917, by which time Mabel was 37 years old.

While living with Ath in Sutton there is nothing to suggest that Mabel had any work in which to be 'passionately interested' prior to her employment with the BBC. There is evidence, however, of her considerable involvement in amateur dramatics, an interest shared with her husband and moving beyond the local amateur company in Sutton. ${ }^{11}$ In January 1923 The Times reviewed a popular comedy, French Leave, performed by Lloyds Dramatic Society. Mrs Constanduros and Mr A. Constanduros are listed, and Mabel is picked out for her performance as 'the voluble landlady of the Brigade billet'. ${ }^{2}$ Around or just before this time, Mabel sought opportunities for dramatic training. Marion Cole, a student with Elsie Fogerty at Central School of Speech and Drama, describes a Thursday afternoon diction class held at rooms in the Albert Hall: 
There was a little woman, married, who struggled with lovely lyrics, which her strangely husky voice just did not suit; but it was clear that she loved poetry and Fogie was always encouraging to her. One day she spoke a charming poem which nobody knew, her whole voice changed. Fogie looked up with her special smile and said 'Dear, it's come! Your breathing - control - everything. Now you are free! You wrote that ... Yes - I think you will be able to write too. Bring me something quite different next time, dear, please ... I'm so very glad: I knew you could do it.' Next week, 'something quite different' was a sparkling cockney sketch, also original, which had us helpless with laughter: but this great little artiste, once in command of her own voice, could reduce us to tears just as easily. Her name was Mabel Constanduros. (Cole, 1967: 88)

Through the unavoidable elaborations of a moment recalled after a gap of forty-five years, the sense of a liberating change being recognised by those in that upper room of the Albert Hall is inescapable, and chimes all too clearly with Constanduros's own recollections of

Miss Fogerty [who] was the greatest help and encouragement to me. She used to make me write more and more monologues, and it was her appreciation that perhaps gave me courage to go through the door of Broadcasting House on that February morning in 1925 - the door that led to a new life. (Constanduros, 1946: 38)

The BBC's Written Archive Centre (BBC WAC) reveals the strength of Constanduros's business voice, especially when she is writing to negotiate fees for the many characters she created for radio.

As a writer, Constanduros's first contract appears to have been signed on 19 January 1926, when a fee of ten guineas was agreed for the play Devoted Elsie and the '[n] ame of author to be b'cast [broadcast] as author'. ${ }^{13}$ Billed as a 'radio comedy', it was broadcast in February of that year with Constanduros as the eponymous Elsie, working in the kitchen with the cook, where, 'to help pass the time away whilst hard at work, they discuss with vital interest Mr. 'Arold. Elsie's admiration of Mr. 'Arold is beyond description.' ${ }^{14}$ This was not, however, the first time that she had performed her own material. The first record of a 'comedy sketch by Mabel Constanduros' is dated 14 September 1925, but 'A Day in the Country' by Mabel Constanduros was broadcast earlier on 18 July, and she is named as an individual performer/entertainer on 29 June. Her first featured broadcast appears in records for $1 \mathrm{May},{ }^{15}$ which coincides with her own account: 
I was offered my first solo broadcast in the spring of 1925. I went to see Kenneth Wright, who said they were prepared to pay me two guineas for a five minute's broadcast, provided that the material was original and that the B.B.C. would not have to pay any copyright for it [...] soon after this my friend K.H. Wright sent for me again and told me that he thought I was not being paid enough and that they proposed to raise my fee to three guineas. A few weeks later still they sent for me again and told me they proposed to make me a star (which meant five guineas). (Constanduros, 1946: 42-3)

This marked Constanduros's sense of the move across 'the dividing line' between being an amateur and a professional: 'A professional writer or performer may never fall below a certain level of achievement, though her work may be above that level often' (1946: 43). As a professional writer she quickly developed a series of characters for herself as a professional $\mathrm{BBC}$ performer. Her understanding of the burgeoning industry she had entered, the demand for new entertainment product in a format that was familiar and instantly recognisable to her listening audience, is remarkable at this early point in broadcasting history:

One voice is apt to become tiresome on the air if it goes on for a long time, so I invented my cockney family - Mrs Buggins, the good natured, much tried housewife; Grandma (an old tartar if there ever was one); and two children. Occasionally I added neighbours, and Aunt Maria who came from the North. I think seven voices was the greatest number I ever attempted in one broadcast, but being several people at once enabled me to do sketches, which I think more entertaining than monologues. (1946: 43)

'Mrs Buggins Chooses a Hat' went out on 29 August 1925, with 'The Buggins Family Out for the Day' broadcast on 2LO (London) on 1 September, at 8 o'clock in the evening. The BBC copyright files are very thin for the decade between 1925 and 1935, and her 'artist's file' doesn't begin until 1935, but it is worth noting that in a letter dated 6 December 1927 she writes to enquire about 'how to proceed' in relation to a song of hers that has been broadcast without her permission. Mr Howgill replied for the $\mathrm{BBC}$, stating that the singer did not include it in the programme that she had submitted before broadcast, and he asks Constanduros to go and see him, at which point, one must assume, an apology, and possibly a fee, was accepted. In the 900 entries for Mabel Constanduros gathered together in the BBC Genome project, she is referred to as an 'entertainer' performing 'selections from her Repertoire'. Sketches 'written' by her 
and issues of copyright and overseas broadcast relating to longer pieces are evidently of concern where she is formally identified as the 'author'. What is clear is that from the very start of her career Constanduros was a determined negotiator, and little seems to have stood in the way of her rapid professional progress; least of all, her husband.

\section{Male company}

Jennifer Purcell's interviews with Mabel Constanduros's family, particularly her nephew and later co-writer Denis Constanduros, confirm that Athanasius was a cautious, quiet, 'latter-day Mr Pooter' (Purcell, 2014: 7-8). Mabel's brief reference to his concern that their neighbours might hear her typing her sketches and articles - 'to his mind such an occupation was beneath my dignity' (Constanduros, 1946: 65) - led me to wonder why there seemed to be no evidence of the expected resistance to her pursuing her new-found professional life. But then I looked again at the early $\mathrm{BBC}$ contracts and began to question his signature as witness. I have no proof of forgery but merely note that the two signatures, Mabel's and her husband's, are surprisingly similar. From 'tenshilling articles' for magazines and two-guinea sketches for the BBC in 1925, Constanduros received six guineas for a sketch on 2 January 1928, followed two months later by twelve guineas for a play, The Strutham Amateurs Rehearse Dick Whittington, which was broadcast on 9 April of that same year. Constanduros is credited as author and also appears in the cast list alongside Michael Hogan, with whom she began a significant performing and writing partnership.

Constanduros records that the first Radio Repertory Company consisted of eight to ten people, only two of whom were women. Phyllis Panting had even less acting experience than Constanduros, being a fashion journalist and editor for a women's magazine (later Woman's $O w n)^{16}$ but, like Constanduros, she quickly settled into writing and performing for radio. At the end of 1925 Constanduros reported that a new actor had joined the Radio Rep: 'I was struck at once by his excellent cockney accent and the charm of his speaking voice in straight parts. His name was Michael Hogan' (Constanduros, 1946: 41). The almost coy understatement of this introduction to Hogan in her autobiography is followed by a reported verbal exchange which seems at odds with other representations of her vocal independence and self-confidence. 
One day, as he and I were snatching a hasty meal at Lyons' between a rehearsal and transmission, we were talking about the poor material we were given sometimes to put over.

'Why shouldn't we write a play?' he asked. 'Not a one-act play; a long one.'

'But Michael, I couldn't,' I said.

'We could together,' he insisted. 'I'll go and see R. E. Jeffrey and get him to commission it.' He did, and we wrote it. (1946: 41)

The Survivor, 'A mystery in three acts by Michael Hogan and Mabel Constanduros', was broadcast simultaneously on 29 May 1928 on three of the regional stations, including $2 \mathrm{LO}$ (London), at 9.40 in the evening. ${ }^{17}$

Although he was not without professional experience, it is surprising to find Hogan billed first, before his more established collaborator. A month later, on 12 June and 26 June, Michael Hogan witnessed Constanduros's signature for two contracts (worth $£ 25$ and $£ 20$ respectively) relating to a 'Mrs Buggins' revue. ${ }^{18}$ In another contrasting narrative voice, Constanduros reported that ' $[\mathrm{s}]$ oon after I met Michael Hogan, I asked him to join the Buggins family as "Father", and for seven years we wrote broadcast material together and travelled all over the country doing concert work' (1946: 46). In 1927 Constanduros and Hogan created a spin-off from the Buggins, $\mathrm{Ag}$ and Bert, for which they are both credited as writers for the 31 August broadcast. ${ }^{19} \mathrm{Ag}$ and Bert is also listed as appearing on Sunday performances at the Arts Theatre, London, in December $1928,{ }^{20}$ and the IMDB lists a 1929 film (sketch) of $\mathrm{Ag}$ and Bert in which both Constanduros and Hogan appear, but here Constanduros alone has the writing credit. There is no contract evidence of their joint work until 1936, when Constanduros writes on 1 May to question the $£ 25$ fee they have been offered, stating that previously they had each received $£ 50$ 'for the last two similar shows we wrote. If this one is going to be done twice that's all right, but I don’t think $£ 25$ is enough. ${ }^{21}$ A reply dated 4 May informs her that the work is not scheduled for repeat broadcasting and offers 35 guineas and an agreement for a further 15 guineas if there is a repeat transmission. It is clear that Constanduros's voice led the negotiations for this successful partnership.

In the winter of that year she suddenly dropped out of a planned Buggins Christmas broadcast and boarded a ship for America with her friend, the actress Grizelda Hervey. Hogan did not go with her but appears on the passenger list of the same ship, the Normandie, three years later. The IMDB has writing credits for him on three Hollywood films, beginning with Rebecca (Alfred Hitchcock, 1940). Constanduros 
is notably silent, making no reference to their decision to go their separate ways, professionally or personally, and no further reference to him appears. Her contractual wranglings now concern her work with two other writing partners: her nephew, Denis, and Howard Agg. These two collaborators alone were included by Val Gielgud (head of Radio Drama, BBC) in Mabel Constanduros's obituary in 1957, with no mention of Hogan. ${ }^{22}$

Constanduros returned to England in spring 1937 as she was increasingly concerned about her son. Buried in a chapter largely voicing maternal concern for Michael, his health, his lack of settled employment and his hopes of marrying Constanduros's former secretary, is the briefest of references to the death of her husband..$^{23}$ A more distracted voice on the impact of Ath's death can be heard in her letter of 14 July 1937, but only as an aside to the main purpose of her correspondence with the $\mathrm{BBC}$, in which Constanduros is, once again, fee wrangling. She begs forgiveness for

not having answered before your letter of July gth but the sudden death of my husband on that date has thrown all my affairs into confusion. I consent to the terms set out in that letter concerning the musical play Horti-mania on behalf of my nephew and myself. ${ }^{24}$

Denis and she were a successful writing partnership, creating another popular radio series, The English Family Robinson and later having a play, Acacia Avenue (1943), running in the West End, also adapted as 29 Acacia Avenue for release as a film. There is no doubt that Constanduros did much to open doors for Denis, who was to become a highly respected radio and television writer in his own right, but she was also sure to make it clear that she was the senior and more experienced writer in the partnership, and she expected recognition of that fact, as seen in a letter dated 2 September 1937:

\section{Dear Mr Hamilton Marr}

If you consult your files you will find that you paid me fifteen pounds or guineas - for both my Conversations in the Train. It was my nephew, Denis, who got twelve pounds. I am quite willing to accept the same fee as I had before for this one. ${ }^{25}$

Later correspondence with Hamilton Marr, dated 11 May 1939, continues in similar tone, reinforcing her clear sense of the commercial competition to the $\mathrm{BBC}$ monopoly and the opportunities emerging for creative artists, insisting on fair dealing, and throwing in a personal appeal for good measure: 
I'd be awfully glad if you could see your way to paying a little more than fifteen guineas for our Play ... It does seem very little, especially if it is to include a relay to Empire, because now I can generally sell my things separately to Australia and Canada. Of course I know it sometimes can't be managed, but, as I have said before, original work seems to be paid so much less adequately than adaptation. I cannot understand it. Do your best for us, won't you? ${ }^{26}$

In this instance she was refused and accepted the lower fee.

Constanduros continued to be the leading negotiator in her writing partnership with Howard Agg, at least initially. He is introduced in her autobiography on the last few pages, although they began writing together in 1937, and it is only in this last partnership that she speaks of the difficulty of having to consciously develop a method of working collaboratively. Their main interest was in plays for amateurs, a flourishing market, with Samuel French's editions leading the field. Constanduros had first-hand experience of amateur companies, and her successful commercial exploitation of that market in sketches, monologues and duologues has resulted in at least two of her pieces remaining on French's lists today. Agg already had a section of that market in mind:

So we talked out a plot for an all-women play, since Howard had always specialized in these [...] It was a hopeless business. Our minds worked in different directions; we could not pull together at all [...] We were fired with the idea of making a volume of six plays for women, and we did eventually achieve this with some difficulty for he was employed during the day at other things and so was I. (Constanduros, 1946: 129)

Agg appears to have been on the staff of the BBC, but it is not clear what his 'day job' was or if it started before or after he began writing with Constanduros. ${ }^{27}$

As well as maintaining her performance and writing career for radio, Constanduros was working in film, writing songs, and had several successful stage appearances. She devotes a chapter of her autobiography to theatrical touring, and particularly theatrical landladies (1946: 79-87). She stopped touring when war was declared in 1939, returning to her radio broadcasts and writing:

Writing with Howard was a great solace during the war. From plays for amateurs we turned our attention to writing for broadcasting. From the autumn of 1940 to the autumn of 1943 I think we wrote fifty that were accepted. (1946: 130) 
The gently insistent tones of Constanduros's negotiating voice give way to Agg's sometimes 'flip' and certainly arrogant voice as he takes over negotiations with the BBC, accepting and signing contracts on their behalf from the summer of 1940 . He requests a fee of 35 , not 30 guineas, for their play The Lady From Abroad, adding that 'if you cannot do this, of course, we shall quite understand'. ${ }^{28}$ The issue for the BBC appeared to be the length of the piece, and it was pointed out that accurate timing of pieces had to be clear so that fees would be consistent. On 24 October of that year, Val Gielgud wrote a memo requesting that the copyright office negotiate with Constanduros and Agg for The Man from the Sea, adding 'perhaps at the same time you would note Mr Agg's change of address'. Subsequent letters to Agg are addressed to him at Constanduros's cottage, Prattenden's, in Bury, West Sussex. On 1 November Agg returned the signed contract, again from Prattenden's, adding: incidently [sic], would you please instruct whoever is responsible to make payment out to me when it comes due, as I am looking after this side of our partnership' ${ }^{29}$ This was apparently carried out, with no evidence to suggest that Constanduros had agreed. She seems to have been silent on the matter.

Constanduros refers to having decided to let her cottage for the duration of the war and writes from 9 Wetherby Gardens in London, until she speaks of moving back to Sussex 'when the flying bombs came over' (Constanduros, 1946: 76). Agg also writes from 9 Wetherby Gardens from 1942, and from New Cottage, West Burton (the neighbouring village to Bury) in $1945 .{ }^{30}$ Agg and Constanduros produced a great deal of radio broadcast material, so much so that in December 1940 they asked that their adaptation of a novel for radio be credited to 'Peter Peveril', as their names had 'appeared against a good many plays lately.' ${ }^{31}$ The extent of Constanduros's abdication from matters of money in their joint work did not extend to the work itself, which in the later 1940s included adaptations of Dickens's major novels. Constanduros's creative voice sounds clearly and most delightfully in $\mathrm{Mr}$ and Mrs Sparkes, a situation comedy which is a funny, yet toe-curlingly painful representation of the 'quiet, domesticated couple living in a small suburban house near London'. If there was a voice missing from Constanduros's married life in Sutton, it might be said to have been found here in the Sparkes' 'neat bright, soulless-looking room [...] quite pleasant and comfortable but, like hundreds of its kind, entirely without character' (Constanduros and Agg, 1941: Introduction. See Figure 34. ${ }^{32}$ Working with Agg did not stop Constanduros from continuing to write with Denis, nor does Agg's negotiating stance drown out her own voice in the pursuit of royalties. 


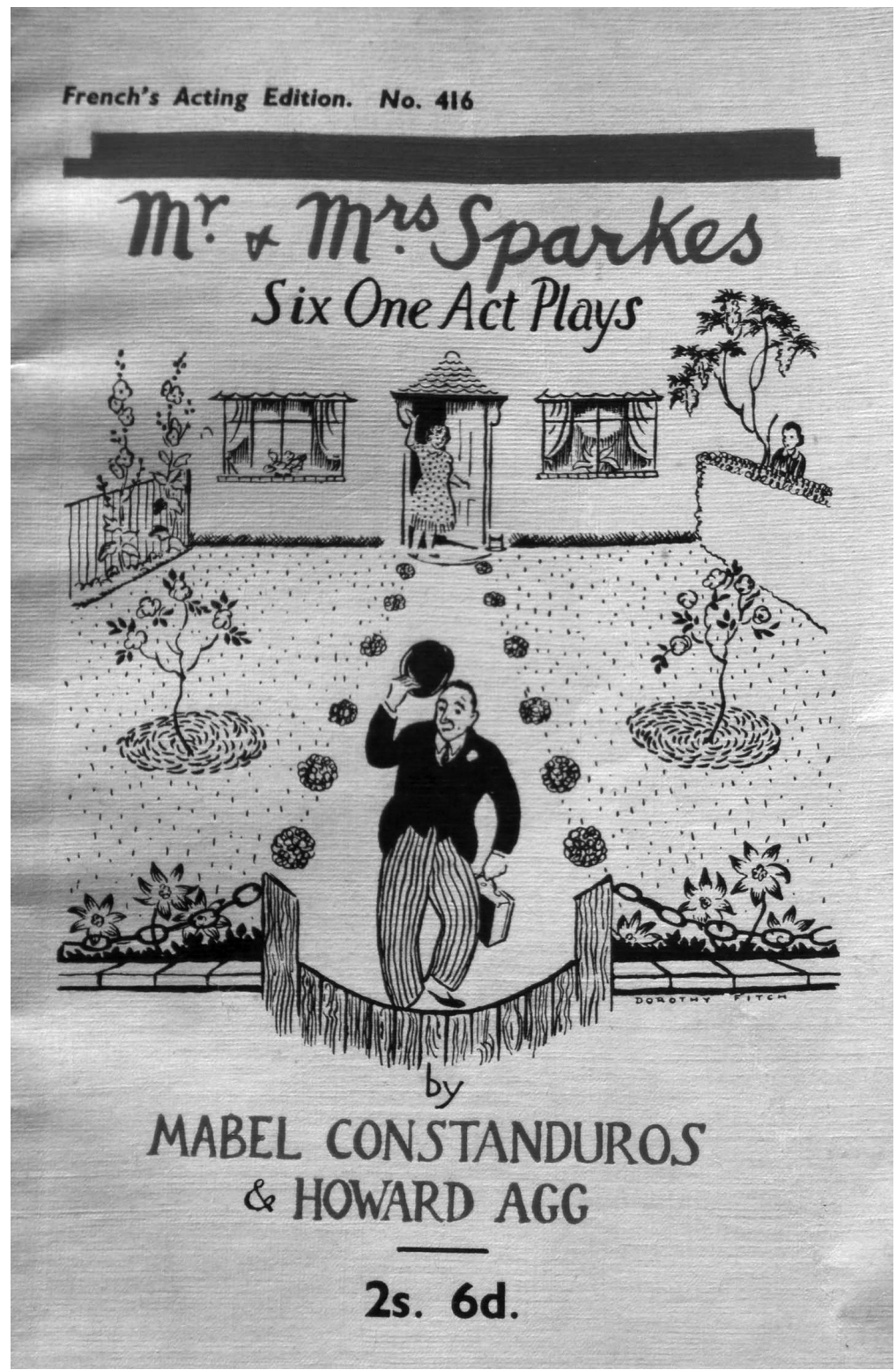

34 Mr \& Mrs Sparkes: Six One Act Plays, 1941, by Mabel Constaduros and Howard Agg. 
In 1943 she sought the support of the Society of Authors in her battle against a publisher who was refusing to give proper sales accounts or return the plays he held so that she could hand them to the more reliable management of Samuel French. The Society of Authors pointed out that, first, she had failed to renew her membership for the previous two years and, secondly, some of the rights issues she was complaining about would be solved if she joined the League of British Dramatists, which would act as agents for such sales. The subsequent exchange demonstrates the often indignant edge that Constanduros's professional voice could reveal:

\section{Dear Mr Kilham Roberts,}

I hadn't heard of the League of British Dramatists before. Do I understand that it is an affiliated society to that of the Society of Authors, and that it undertakes to act as author's agent?

In this case, does it undertake to offer material and has it the staff to offer it in foreign serial and other markets?

Does it undertake to offer the material of all its members? This would seem to me to be a dangerous policy as many utterly incompetent people might join simply in order to have their goods marketed. Also, what commission does the society charge for acting as author's agent? Surely the membership fee doesn't include that? ${ }^{33}$

She received a swift reply dated 25 May 1943, giving her the required information, but by the end of that year she had written to say that she no longer wished to continue membership - though it is unclear whether she ever in fact held it.

\section{Voicing difference}

Mabel Constanduros placed a great deal of emphasis on the voice as the conveyor of truth. For her, the voice, not the eye, is the window to the soul: 'I find voices a great indication of character, especially if one's ear has a clear field to judge them and is not distracted by the impression the eye is sending at the same time to one's brain' (Constanduros, 1946: 129). She celebrates the freedom that radio gives her to be 'whatever character you choose, since your appearance can neither help nor hinder', but warns that the freedoms of apparently limitless artifice are constrained: ' $\mathrm{t}]$ he microphone is merciless, though, to affectation and insincerity. The moment you cease to mean what you say, listeners will find you out' (1946: 39). The 'listeners' are the unseen, all-important 
recipients of information, entertainment and instruction, enjoyed in an unlimited collective experience within Reith's paternalistic vision of cultural, if not social, equality:

[B] ecause everyone can have as much as they like of it, broadcasting, at least as delivered by the fledgling $\mathrm{BBC}$, is no respector [sic] of persons; it is the same for everyone: 'Most of the good things of this world are badly distributed and most people have to go without them. Wireless is a good thing, but it may be shared by all alike, for the same outlay, and to the same extent ... The genius and the fool, the wealthy and the poor listen simultaneously ... there is no first and third class.' Broadcasting, said Reith, had the effect of 'making the nation as one man'. (Higgins, 2015: 9, citing Reith, 1924)

This was also an essentially conservative project, and to pick up Alison Light's argument, radio was part of a 'contradictory process of a modernizing conservatism [...] central to the period [the interwar years] and to its formation, or reformation, of Englishness' (Light, 1991: 215).

Reith's democratising vision for the BBC might also be critiqued for its patriarchal assumptions about class and gender difference, an instance of the careless masculinity that has made and continues to make histories that marginalise or simply forget women, and here forgets their role in laying the foundations of today's broadcasting. Hilda Matheson, the first director of 'talks', programmed 'an extraordinarily mixed bag of subject-matter [...] from theatre criticism to economics from foreign affairs to tips for housewives' (Higgins, 2015: 17). While she broadcast the voices of women writers such as Vita Sackville-West, who gave a talk on 'the modern woman', Constanduros was writing and performing a new 'Buggins' sketch. Later in her 'afterword', Light speaks of the influence of the wireless among the other new media, and the 'buried chapter' in her book; one that would have focused on the 'significance of the absurd accents, pealing voices and clipped tones [...] which were once the new and distinctive sounds of class between the wars' (Light, 1991: 215). As she notes, the life and work of the pioneering women we want to reclaim in feminist histories are all too often full of awkward and often uncomfortable contradictions. In their bid for personal freedom, 'what began as a ventriloquy of masculinity and an attempt to emancipate themselves from earlier erotic codes of femininity, locked women into a paralyzing and potentially infinite series of social demarcations against their own kind' (Light, 1991: 215).

If Constanduros's discovery of her 'cockney voice' set her free, in 
the terms Elsie Fogerty first recognised in her diction classes, it also worked to reform and reinforce the conservative values of family and class disturbed so radically in the interwar years, and further, laid the foundations for the much-vaunted idea of the stoicism of the working classes, and particularly Londoners, on which so much wartime propaganda was to rest. A column-length article in the Lancashire Evening Post on 19 April 1937 led with a photograph of Constanduros, who was appearing in No Sleep for the Wicked at the Blackpool Opera House. The headline reads: 'A Voice and A Smile You All Know / Mabel Constanduros to Meet Housewives.' Constanduros is then quoted as follows:

The English working-man's wife is the salt of the earth. I try with Mrs. Buggins to give a faithful picture of how good these people are; how they manage so marvelously in adverse circumstances. They are more important than any other class of beings in England. ${ }^{34}$

The journalist, Sylvia Heath, goes on to comment on the 'sincerity' of Constanduros's voice: she is 'small, quiet-voiced, and sincere. A social worker, who is looking forward to a time when her duties as broadcaster, actress and authoress will allow her to devote herself to the working families.' But her heart is always in Sussex with her '21-year-old son, Michael who is the apple of my eye', she tells the journalist. She then speaks of her nerves when performing, especially before a Lancashire audience who 'are supposed to be difficult', but reminds her audience that 'Aunt Maria of the Buggins family is a Lancashire woman'. The journalist closes with an assurance that 'deep sincerity, a quick wit and a true womanly understanding of others' troubles will make the real person as popular as the voice which has become that of a friend'.

What is so striking here is the mode by which the representation of the 'other' is portrayed as an act of do-gooding, part of a greater social work for 'others'. The Bugginses are not Constanduros or her kind/class/ caste, but they are part of the fabric of nationhood that she is instrumental in making. And the Bugginses are 'good', 'important', and so she 'does good' for them. There is, of course, no acknowledgement of the good the Bugginses did for her in providing her with a living. Constanduros also plays the local card in her own favour, reminding the journalist and the readers of her affectionate and respectful depiction of the Northern woman in 'Aunt Maria'. The Buggins family, the suburban Mr and Mrs Sparkes and the later Robinson family all have their own corners of the local to convey, the specificities of different voices, voicing difference; 
the 'us' and 'them' on which the success of domestic comedy stands and which Constanduros created so well in early radio.

There is one other voice running through Constanduros's autobiography that deserves attention. It is the voice of the constant, live-in, domestic help without whom little of Constanduros's work could have been carried out. She is mentioned throughout, but halfway through the book Constanduros reinforces her place as 'one of us' when she points out that 'Bina, my housekeeper, must certainly have a chapter to herself, because without her I could not have a home' (Constanduros, 1946: 75). Albina M. Smith came to work for Constanduros when 'Michael was about six', at which point they were still living in Sutton with Athanasius.

She had not been in the house a week before I knew what a treasure had been sent to me. She is a beautiful cook, can sew and wash, mend a wireless set or a burnt fuse, make clothes, trim hats, and turn her hand to anything. We have lived together now for more than twenty-four years in great contentment and understanding. She has nursed me with skill and kindness through many illnesses. There is no difficulty that she cannot surmount, no task that she will not tackle; you never see her out of temper or in a muddle. (1946: 75)

This is the stuff of middle-class fiction, or at least envy, for a class increasingly left to its own devices by the diminishing ranks of women prepared to take on domestic work. This 'sturdy', 'dark-eyed' Welsh woman 'with a smile which is lovely because it is so kind' leads Constanduros to admit that ' $[\mathrm{w}]$ hen I am away from Bina I miss her as a child would its nurse' (1946: 75-6). Constanduros heaps four pages of sunny praise on the woman, who also has 'a free and rather Rabelaisian tongue' and no hesitation in wielding a poker in defence of her mistress late at night, when an inebriated man refuses to leave the house having been told that Constanduros does not wish to see him again. 'She is a wonderful friend to have because she is discreet' is the only clue Constanduros gives to there being anything in her domestic life that requires discretion.

Mabel Constanduros's professional success, her life lived separately from her marital home, was made possible by the presence of another woman taking the weight of the domestic duties. This is not to say that Constanduros was not the devoted mother that she portrays in her autobiography, but that the domestic pleasure she enjoyed, in both her London and Sussex homes, was made possible by the domestic stability 
provided for her and her son by Bina. She also employed personal secretaries (Hilda later becoming her daughter-in-law) and gardeners in her Sussex homes. ${ }^{35}$

Constanduros forged a particular kind of freedom for herself during a period that gave unprecedented opportunities to middle-class women in the interwar years. Having found her voice(s), she is revealed as a hard bargainer, a determined professional, an engaging, generous friend and affectionate employer. As a writer and entertainer she has a remarkable grasp of the new medium:

Here is a new kind of entertainment immensely important because it is within reach of everybody, which needs a special technique in writing. It would seem a better policy to encourage authors who understand it to write new radio material, which should be acted by people who understand radio. (Constanduros, 1946: 128)

As she reflects on her long and successful career, her autobiographical voice echoes something of the ambitions expressed by the first director of the BBC. But Constanduros's history of her broadcasting career voices the ambition of an uncompromising professional and a passionate working mother, determined to capture the hearts and minds of her diverse, but essentially middle-class, audience - from whom she is not so very separate.

\section{Notes}

1 The Stage, 3 October 1929, p. 4, https://archive.thestage.co.uk (accessed 30 November 2016).

2 The Buggins Family began its regular run in 1928, but the first sketch to be broadcast, 'The Buggins Family Out for the Day', went out on 1 September 1925 at 8 p.m. Records of broadcast details have been sourced via the work in progress of the BBC Genome project, http://genome.ch.bbc.co.uk, which draws information from the BBC publication Radio Times 1923-2009, specifically http://genome.ch.bbc.co.uk/schedules/2lo/1925-09-01 (accessed 30 November 2016).

3 Clark (2009) provides thirteen sketches first recorded between 1927 and 1932. Scott Jeffs (2016) examines the structure of a Buggins sketch as published for live performance by Samuel French and as captured via transcripts of performance scripts.

4 Time and Tide was a weekly review, first published in 1920.

5 Mrs Miniver became even better known through the 1942 William Wyler film of the same name, focusing on the pluck of the English housewife in 
wartime and credited with influencing the American public's sympathy to US involvement in the Second World War.

6 For more on the legacy of Mabel Constanduros's cockney characters and her modern counterpart in Catherine Tate's 'Nan', see Bush-Bailey (2012).

7 Barry Took in The Oxford Dictionary of National Biography refers to Grandma as 'a crusty, cantankerous old biddy', http://www.oxforddnb.com/ index/101060317/Mabel-Constanduros (accessed 30 November 2016).

8 'Dream Kitchen', British Pathé, 1945, https://www.youtube.com/watch?v $=\mathrm{Y}_{9} \mathrm{DH}_{3} \mathrm{YlCdg}$ (accessed 30 November 2016).

9 For more detail on Mabel's family life and possible early subjects for her 'cockney' creations, see Purcell (2014). My thanks to Jennifer Purcell for her generosity in sharing materials she has accessed through contacts with the Constanduros families. Although living on separate continents, we have shared research findings and ideas about Mabel via email, skype and in our now annual meetings. Jennifer Purcell is currently preparing an extended biography of Mabel and Denis Constanduros.

Constanduros's autobiography is dedicated to the memory of her mother 'and Tony'. The third child is not named and possibly did not reach full term.

11 Constanduros is always enthusiastic about her amateur dramatic experience, citing the many professional performers and writers who started their careers in amateur dramatic companies (Constanduros, 1946: 36-7).

12 'Lloyds Dramatic Society', The Times, 10 January 1923, p. 12, http://www. thetimes.co.uk/tto/archive (accessed 27 January 2016).

13 The contracts and correspondence between the BBC and Mabel Constanduros and her collaborators are used with kind permission of the BBC Written Archives Centre (hereinafter referred to as BBC WAC). Mabel Constanduros, File 1A, 1926-1938.

14 BBC Genome. Devoted Elsie was broadcast on the Regional Programme, appearing first on 5 February 1926, 5 WA Cardiff; 12 February, 5 SC Glasgow; 15 February, 2BE Belfast; and 26 February, 6BM Bournemouth. There does not appear to be a record for $2 \mathrm{LO}$, which identifies a London broadcast. Although the Regional Programme broadcasts were local transmissions, they all came under the BBC's broadcast monopoly. At the outbreak of war in 1939, they were merged under the umbrella of the Home Service, which then broadcast simultaneously across Britain.

15 BBC Genome.

16 Phyllis Panting is also credited with placing Mabel's articles and short stories in the press (Constanduros, 1946: 63).

17 BBC Genome.

18 BBC WAC, copyright, file 1A, 1926-1938.

19 BBC Genome.

20 The Times, 10 December 1928, p. 12.

BBC WAC, copyright file, 1A, 1926-1938. 
22 The Times, 9 February 1957, p. 1. Hogan's apparently sudden disappearance from Constanduros's professional and personal life in 1936 is complicated further by West Sussex local histories, which suggest that Hogan once occupied a cottage in the village of Bury, where Constanduros still owned and occupied her house, Prattenden's.

23 Athanasius's 'sudden death' at his home in Sutton was noted in several local newspapers, always with reference to his relationship to the 'radio star Mabel Constanduros' (Gloucester Citizen, 10 July 1937, p. 1); “Mrs Buggins” Widowed', Western Gazette, 16 July 1937, p. 13. If there had been early money troubles - and Mabel refers to Ath's ongoing pessimism about the future of insurance broking - he was recorded as leaving the net sum of $£ 7,5545 \mathrm{~s} 9 \mathrm{~d}$, and his will directed that if his son, Michael, did not wish to take over the business, it was to pass to his two clerks (Gloucestershire Echo, 7 September 1937 , p. 1). Michael did take over the business and ran it successfully (Constanduros, 1946: 105).

24 BBC WAC, copyright, file 1A, 1926-1938.

25 Ibid.

26 BBC WAC, copyright, file 1B, 1939-1940.

27 BBC WAC, copyright, file 2A 1941-1942, contract for 40 guineas fee for Constanduros and Agg's Laughing Mirror, dated 31 October 1941, and signed by Agg includes a note stating that he was able to secure higher fees when co-writing with Constanduros, otherwise he should receive staff fees. A separate file under Agg's name, identified as Agreements file 1942-1950, makes reference to Agg's BBC office (Room 431, Aeolian Hall) with reference to Constanduros and Agg's radio adaptation of Dickens's Bleak House (the last of thirteen episodes was broadcast on Sunday 7 January 1945) assigning all rights to the $\mathrm{BBC}$ for the considerable sum of 200 guineas.

28 BBC WAC, copyright, file 1B, 1939-1940, Agg/Candler letters, 30 August, 10 and 13 September 1940.

29 BBC WAC. The affirmative response is dated 4 November.

30 BBC WAC, Agg's contract agreement files 1942-1950.

31 BBC WAC, copyright, file 1B, 1939-1940, contract letters regarding Yellow Streak, 17 November-18 December.

32 The six one-act plays for three or four characters are introduced with a note that they first appeared on BBC Radio. Richard Goolden played Nelson Sparkes (Ducksie) and Mabel, Mrs Sparkes (Mummie). There were no little Sparkes.

33 British Library, Add MSS 63220, 1939-49, Society of Authors, letter dated 21 May 1943.

34 Lancashire Evening Post, 19 April 1937, p. 5.

35 My thanks to Jennifer Purcell who provided me with information from the Constanduros family scrapbook in which an obituary notice in the Yorkshire Evening News (n.d.) states that Mabel left Miss Albina Smith (Bina) £150 per annum, and $£ 50$ per annum to her gardener, Fred Ansett. 


\section{References}

Bush-Bailey, Gilli (2012), 'Women Like Us', Comedy Studies, 3.2, pp. 151-9.

Clark, William J. (2009), 'Mabel Constanduros, The Buggins Family', recording, Windyridge Variety Series, http://www.musichallcds.co.uk (accessed 11 September 2018).

Cole, Marion (1967), Fogie: The Life of Elsie Fogerty, Pioneer of Speech-training for the Theatre and Everyday Life, London: Peter Davies.

Constanduros, Mabel (1927), 'Cheering Up Maria', in Maggie B. Gale and Gilli Bush-Bailey, eds, Plays and Performance Texts by Women 1880-1930: An Anthology of Plays by British and American Women from the Modernist Period, Manchester; Manchester University Press, pp. 636-41.

Constanduros, Mabel (1946), Shreds and Patches, London: Lawson and Dunn.

Constanduros, Mabel, and Howard Agg (1941), Mr and Mrs Sparkes, London: Samuel French.

Higgins, Charlotte (2015), The New Noise, London: Guardian Books.

Light, Alison (1991), Forever England, London: Routledge.

Purcell, Jennifer (2014), “Behind the blessed shelter of the microphone”: Managing Celebrity and Career on the Early BBC - Mabel Constanduros, 1925-1957', Women's History Review, 24.3, pp.372-88, DOI: 10.108o/o9612025.2014.964068 (accessed 11 September 2018).

Reith, John (1924), Broadcast Over Britain, London: Hodder and Stoughton.

Scott Jeffs, Carolyn (2016), 'Voice, Personality and Grandma: Mabel Constanduros and the Buggins Family', Comedy Studies, 7.2, pp. 124-36.

Took, Barry (2016), 'Constanduros, Mabel (1880-1957)', Oxford Dictionary of National Biography, Oxford: Oxford University Press, http://www.oxforddnb. com/view/10.1093/ref:odnb/9780198614128.001.0oo1/odnb-9780198614128-e-6 0317 (accessed 30 November 2016). 